\title{
Publisher Correction: MethCORR modelling of methylomes from formalin-fixed paraffin- embedded tissue enables characterization and prognostication of colorectal cancer
}

\author{
Trine B. Mattesen (1), Mads H. Rasmussen (10), Juan Sandoval, Halit Ongen (1D, Sigrid S. Árnadóttir, \\ Josephine Gladov (1), Anna Martinez-Cardus (D, Manuel Castro de Moura, Anders H. Madsen, Søren Laurberg, \\ Emmanouil T. Dermitzakis (10), Manel Esteller (1), Claus L. Andersen (1) \& Jesper B. Bramsen (1)
}

Correction to: Nature Communications https://doi.org/10.1038/s41467-020-16000-6, published online 24 April 2020.

The original version of this Article contained an error in Fig. 2d, in which all the numbers appeared as bold instead of either normal or bold type setting to indicate statistical significance of FDR $<0.05$. This has been corrected in both the PDF and HTML versions of the Article.

Published online: 03 June 2020

\footnotetext{
(c) (i) Open Access This article is licensed under a Creative Commons Attribution 4.0 International License, which permits use, sharing, adaptation, distribution and ceproduction in any medium or format, as long as you give appropriate credit to the original author(s) and the source, provide a link to the Creative Commons license, and indicate if changes were made. The images or other third party material in this article are included in the article's Creative Commons license, unless indicated otherwise in a credit line to the material. If material is not included in the article's Creative Commons license and your intended use is not permitted by statutory regulation or exceeds the permitted use, you will need to obtain permission directly from the copyright holder. To view a copy of this license, visit http://creativecommons.org/licenses/by/4.0/.
}

(c) The Author(s) 2020 